\title{
Assessing The Market's Reaction To The Dodd-Frank Act
}

George Turk, Florida State University, USA

Philip Swicegood, Wofford College, USA

\begin{abstract}
In this paper, we exam how the financial markets reacted to the emergence of the Dodd-Frank Wall Street Reform and Consumer Protection Act as it developed through the legislative process from policy concept to signed law. We find that investors, on the one hand, desired clarity and sustainable oversight of market activities, but simultaneously feared the possibility of overburdensome regulation. As the legislative process developed, markets cheered any watering down of perceived over-restrictive provisions with a positive response. We also empirically noted the smaller banks' stocks were generally unaffected by the entire emergence of Dodd-Frank, with nearly all of the market reaction (positive and negative) occurring with larger banks' stocks.
\end{abstract}

Keywords: Dodd-Frank Act; Regulation; Legislation; Bank; Market Reaction

\section{INTRODUCTION}

An Act to promote the financial stability of the United States by improving accountability and transparency in the financial system, to end "too big to fail", to protect the American taxpayer by ending bailouts, to protect consumers from abusive financial services practices, and for other purposes. - Preamble of the Dodd-Frank Act

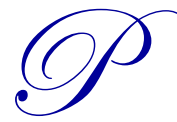

roposed in June 2009, the Dodd-Frank Wall Street Reform and Consumer Protection Act (DFA) was signed into law on July 21, 2010, becoming Public Law No: 111-203. The ceremonial event marked the culmination of a 1-year, 1-month, and 4-day regulatory reform legislative process that produced one of the most far-reaching financial reform bills in the two hundred plus years of government attempts to legislate and/or regulate the U.S. banking system. The DFA was proposed as "a sweeping overhaul of the financial regulatory system, a transformation on a scale not seen since the reforms that followed the Great Depression." With goals expounded in its title, the bill's objectives, pronounced by its authors, are "to promote the financial stability of the United States by improving accountability and transparency in the financial system, to end "too big to fail", to protect the American taxpayer by ending bailouts, to protect consumers from abusive financial services practices, and for other purposes."

With foundation in Ball, et al. (1968) and Fama, et al. (1969), several papers have examined empirically institutional performance (via capital market wealth effects) and the information relevance of key events in the banking reforms' legislative processes. These studies, along with the ex-post impacts of the reform bills, have provided valuable insights into investors' responses to new regulations/deregulations that may affect financial institutions' risk, competitiveness, and overall performance. Using traditional event-study methodology advanced by Brown, et al. (1985) and Malatesta (1986), our research provides an empirical analysis of financial institutions' returns data for evidence of stock market wealth effects related to specific events that occurred as the DFA ventured through the arduous legislative process.

Given the degree of market angst and pain from the recent financial crisis, we find empirical evidence that the markets were generally supportive of modest banking reform. However, markets were fearful of some of the

\footnotetext{
${ }^{1}$ The White House, Office of the Press Secretary, Remarks by the President on 21 st Century Financial Regulatory Reform, EDT, June 17, 2009
}

(C) 2012 The Clute Institute http://www.cluteinstitute.com/ 
political rhetoric coming from Washington, D.C. suggesting extreme reregulation; so whenever key provisions in the bill were watered down through the legislative and lobbying process, markets showed a positive response. We also determine that the market response was only significant among larger banking institutions.

\section{BACKGROUND OF THE DFA}

The 73-month economic expansion that ended in December 2007 saw housing prices demonstrate rapid and widespread gains, reaching an apex in July $2006 .{ }^{2}$ In 2008, U.S. banks, with average annual failure rates of less than four during the expansion period, ${ }^{3}$ began to fail at an alarming rate. Twenty-five banks required the Federal Deposit Insurance Corporation's (FDIC) resolution services in 2008 and by mid-June 2009, an additional 37 banks were resolved. On June 17, 2009, President Obama announced that his administration "is proposing a sweeping overhaul of the financial regulatory system - a transformation on a scale not seen since the reforms that followed the Great Depression." ${ }^{\circ}$ A same-day 88-page white paper release by the Department of the Treasury outlined the five objectives of the proposed legislation: ${ }^{5}$

1. Promote robust supervision and regulation of financial firms

2. Establish comprehensive supervision of financial markets

3. Protect consumers and investors from financial abuse

4. $\quad$ Provide the government with the tools it needs to manage financial crises

5. Raise international regulatory standards and improve international cooperation

If enacted, the sweeping overhaul would ensure the role of the federal government will be "greatly expanded in almost all aspects of the financial sector of the economy and will affect consumers, investors, and managers of financial service firms (Barth, et al., 2010)."

Subsequent to the President's announcement, the public's enduring uneasiness of the vulnerabilities within the financial and economic environments most perspicuously demonstrated, through consistently greater volatility in stock market indices, increasing numbers of FDIC-initiated bank resolutions, ${ }^{6}$ rising unemployment and foreclosures rates, and significant losses of wealth via adversely affected home values, mitigated some of the public outcry critical of additional banking regulations, and centered the political debates on the depth and the scope of the reforms, rather than on the apparent validity of the bill's eventual passage.

The House of Representatives passed its version of the bill - H.R. 4173 - on December 11, 2009. The bill was engrossed in the Senate on May 20, 2010. Debate on three key issues - the consolidation of regulatory power within the newly created Consumer Financial Protection Bureau (CFPB), the proposed ban on proprietary trading for banks and bank holding companies (i.e., the Volcker Rule, not proposed in original House bill passed on December 11, 2009), and the Lincoln proposal that prohibits federal assistance to any swaps entity, requiring banks to spin off derivatives activities - proved to be most contentious aspects for reconciliation, even within the singleparty controlled Congress. First, considered as a stand-alone regulatory agency, the CFPB will be independently funded but housed within the FRB. The Volcker rule (proprietary trading) was amended to allow banks to invest a maximum of three percent of Tier 1 capital in hedge funds and private equity funds but limits their ownership in these funds to three percent. The derivatives proposal was amended to allow banks to continue dealing in interest rate, foreign exchange, gold or silver swaps, and hedging activities. Reconciliation between the House and Senate versions of the bill was announced on June 25, 2010. The bill was enrolled in the House and the Senate on June 30 and July 15, 2010, respectively, and was signed into law on July 21, 2010.

\footnotetext{
${ }^{2}$ S\&P/Case-Shiller Home Price Indices peak in: June 2006 (10-city composite); July 2006 (20-city composite); 2006 22 (quarterly composite of single-family home price indices for the nine U.S. Census divisions)

${ }^{3}$ In 2002, there were 11 bank failures; excluding 2002, the average annual bank failure rate was only 2.0 during the final five years of the expansion period ending immediately prior to 2008 and 2009.

${ }^{4}$ From "Remarks by the President on $21^{\text {st }}$ Century Financial Regulatory Reform"; East Room; 12:53 p.m.

${ }^{5}$ Financial Regulatory Reform, A New Foundation: Rebuilding Financial Supervision and Regulation; An 88-page white paper released by the Department of the Treasury, June 17, 2009

${ }^{6}$ One-hundred and ninety-nine banks failed between June 17, 2009 (announcement date) and July 21, 2010 (DFA signing). (FDIC) 
Although enacted, much work remains to be done as the DFA contains more than 40 provisions for studies of the financial system and more than 300 provisions for rule-making, primarily through four agencies: 1) the Securities and Exchange Commission (SEC), 2) the Board of Governors of the Federal Reserve System, 3) the Commodity Futures Trading Commission (CFTC), and 4) the Consumer Financial Protection Bureau. ${ }^{7}$ In addition to these provisions, the DFA provides for more than 580 amendments to over 100 existing Acts, Statutes, and U.S. Code.

\section{EMPIRICAL STUDIES}

Since the Banking Act of 1864, approximately two-thirds of all major banking bills that have entered the domain of public law have done so within the past 35 years. Following the pioneering work of Ball, et al. (1968) and Fama, et al. (1969), many event studies that utilize similar, but varying, empirical methods to test for wealth effects associated with the necessary legislative events that occur during the rule-making process as it relates to the passage of the different banking laws that have been published. For instance, major event study analysis has been conducted on the effects of the Depository Institutions Deregulation and Monetary Control Act of 1980 (Aharony et al., 1988; Allen and Wilhelm, 1988), the Garn-St. Germain Depository Act of 1982 (Cornett and Tehranian, 1990), the Financial Institutions Reform, Recovery, and Enforcement Act of 1989 (Sanduram et al., 1992; Bryant and Martzoukas, 1998), the Financial Deposit Insurance Corporation Improvement Act of 1991 (Swicegood, 1997; Liang et al., 1996), and the Graham-Leach-Bliley Act of 1999; Akhigbe and Whyte, 2004).

Only one empirical study of the relationship between the legislative process of the DFA and stockholder value has come to our attention. Gao et al. (2011) employ a portfolio approach using cross-sectional regressions of cumulative abnormal returns (CMAR) across the study's 17 event dates. Abnormal stock returns for the systemically important banks (assets $\geq \$ 50$ billion) are calculated over each event window by subtracting the average returns from other financial institutions (control group, assets $<\$ 50$ billion) over the same window. They find evidence of negative abnormal stock returns for banks with higher systemic risk or higher levels of derivatives trading, with significance (5\% level) for the Big-6 banks only in the later events. Our study also examines the capital market's reaction to legislative events surrounding the DFA, but we compliment the Gao study through an expansion of the sample data and a closer look at the difference in reaction based on bank size. In addition to the industry's largest players, we include both small- and mid-sized banks in our sample of 366 commercial banks, savings institutions, and bank holding companies.

\section{METHODOLOGY}

\section{Data}

We use data obtained from both the University of Chicago's Center for Research in Security Prices (CRSP) and the Standard and Poor's Compustat quarterly databases to test the effects of the DFA on shareholder wealth. To be included in our sample, firms must be assigned one of the following Standard Industrial Classification (SIC) codes: 6020 (Commercial Banks); 6021(National Commercial Banks); 6022 (State Commercial Banks); 6029 (Commercial Banks, Not Elsewhere Classified); 6030 (Savings Institutions); 6035 (Savings Institutions, Federally Chartered); 6036 (Savings Institutions, Not Federally Chartered); 6711 and 6712 (Bank Holding companies).

The DFA's legislative period encompasses 276 trading days that begin with the President's proposal announcement on June 17, 2009, and end with the President's signature on July 21, 2010. The estimation period includes 100 trading days prior to and following the legislative event period. To remain in the sample, firms must have active returns information available on the CRSP database for the 476-day estimation period. Those firms meeting the classification and returns requirements are subsequently matched to the Compustat database where successful firms will have total assets and Tier 1 risk-adjusted capital ratio information reported for December 31, 2008. The final sample includes 366 financial institutions. Descriptive statistics for the final sample are shown in Table 1.

\footnotetext{
${ }^{7}$ CRS Report for Congress, Rulemaking Requirements and Authorities in the Dodd-Frank Wall Street Reform and Consumer Protection Act, Curtis W. Copeland, Specialist in American National Government, November 3, 2010
}

(C) 2012 The Clute Institute http://www.cluteinstitute.com/ 
Table 1: Descriptive Statistics by Assets

\begin{tabular}{|l|c|}
\hline Median & $\$ 1,345,656,500$ \\
\hline Mean & $\$ 35,022,785,290$ \\
\hline Minimum & $\$ 160,427,000$ \\
\hline Maximum & $\$ 2,175,052,000,000$ \\
\hline Sample size (n) & 366 \\
\hline
\end{tabular}

We test whether the economic crisis surrounding passage of DFA had material impact on the capital level of surviving bank institutions in the sample. Means tests for differences in base year 2008 and Tier 1 ratios versus 2010 Tier 1 ratios appear in Table 2. We find that the capital ratios are marginally improved over the period of examination, ensuring integrity of the overall comparison of the sample banks. ${ }^{8}$

Table 2: Tier 1 Capital Ratio Differences

\begin{tabular}{|l|c|c|}
\hline & $\underline{\mathbf{2 0 0 8}}$ & $\underline{\mathbf{2 0 1 0}}$ \\
$(\underline{\mathrm{n}=366)})$ & $12.52407 \%$ \\
\hline Mean & $11.43492 \%$ & $(4.283971)^{*}$ \\
\hline
\end{tabular}

* Indicates significant at the $1 \%$ level.

\section{Legislative Event Dates}

A detailed description of the twelve key legislative event dates is shown in Table 3 . These dates are a focused sub-set of the dates examined by Gao et al. (2011). These dates were also reviewed for confounding news occurrences.

Table 3: Event Descriptions

\begin{tabular}{|l|l|l|}
\hline Event Number & Event Date & Event Description \\
\hline D1 & $6 / 17 / 2009$ & Obama administration proposes a comprehensive financial regulatory reform plan. \\
\hline D2 & $11 / 10 / 2009$ & Sen. Dodd introduces bill in the Senate. \\
\hline D3 & $12 / 2 / 2009$ & Rep. Frank introduces bill in the House of Representatives. \\
\hline D4 & $12 / 11 / 2009$ & House passes its version of the bill. \\
\hline D5 & $1 / 20 / 2010$ & Obama endorses Volcker rule. Significant resistance announced to portions of the Senate bill. \\
\hline D6 & $3 / 15 / 2010$ & Sen. Dodd introduces a revised version that includes compromises. \\
\hline D7 & $3 / 22 / 2010$ & Senate Banking Committee passes its version of the bill. \\
\hline D8 & $4 / 15 / 2010$ & Sen. Lincoln proposes sweeping derivative market changes. \\
\hline D9 & $5 / 20 / 2010$ & Senate passes its version of the bill. \\
\hline D10 & $6 / 25 / 2010$ & Conference committee begins reconciliation. \\
\hline D11 & $6 / 30 / 2010$ & Conference version passes House. \\
\hline D12 & $7 / 15 / 2010$ & Conference version passes Senate. Promise of support by White House. \\
\hline
\end{tabular}

\section{Model Specification}

Security prices are evaluated using a multivariate regression model based on Zellner's (1962) seemingly unrelated regression framework. The model, used by Brown et al. (1985), Thompson (1985), Binder (1985), Cornett et al. (1990), Swicegood (1997), and many others, measures an event's impact as follows:

\footnotetext{
${ }^{8}$ In our sample, only two firms reported a Tier 1 risk-adjusted capital ratio of less than 6 percent. 


$$
r_{i t}=\alpha_{i}+\beta_{i} r_{m t}+\sum_{k=1}^{K} \delta_{i k} D_{k t}+\varepsilon_{i t}
$$

thus,

$$
\begin{aligned}
& r_{1 t}=\alpha_{1}+\beta_{1} r_{m t}+\sum_{k=1}^{12} \delta_{1 k} D_{k t}+\varepsilon_{1 t} \\
& \vdots \\
& r_{N t}=\alpha_{N}+\beta_{N} r_{m t}+\sum_{k=1}^{12} \delta_{N k} D_{k t}+\varepsilon_{N t},
\end{aligned}
$$

where

$r_{i t}=$ the rate of return of security $\mathrm{i}$ on day $\mathrm{t}$; for $\mathrm{i}=1$ to $\mathrm{N}$

$\alpha_{i}=$ the intercept term; for $\mathrm{i}=1$ to $\mathrm{N}$

$\beta_{i}=$ the beta coefficient of security $\mathrm{j}$ (systematic risk); for $\mathrm{i}=1$ to $\mathrm{N}$

$r_{m t}=$ the rate of return on a equally-weighted market index on day $\mathrm{t}$;

$D_{k t}=$ a dummy variable (a dichotomous variable) that takes on a value of 1 if $t$ is day 0 or day +1 relative to the announcement of event $\mathrm{k}(\mathrm{k}=1, \ldots, 12)$, or a value of 0 otherwise;

$\delta_{i k}=$ the coefficient of information dummy variable for event $\mathrm{k}(\mathrm{k}=1, \ldots, 12)$ for security

$\mathrm{i}$ (a measure of the average abnormal return over the event period); for $\mathrm{i}=1$ to $\mathrm{N}$

$\varepsilon_{i t}=$ the error term on security $\mathrm{i}$ at time t. for $\mathrm{i}=1$ to $\mathrm{N}$

Security i's returns are observed over the 476-day estimation period from January 23, 2009 to December 10, 2010. The CRSP equally-weighted market index serves as the market proxy. The event periods $D_{k}$ are given a value of 1 on both the day of and the day following an event. Should legislative actions occur on successive trading days, as exampled by event D11, a value of 1 is assigned to each event day and, as with the singular events, the ensuing trading day.

\section{Hypotheses Tests}

H1: For each of the twelve major legislative events, the average abnormal returns equal zero.

If major legislative events leading up to the passage of the DFA have no impact on financial institutions' securities returns, the parameter estimates for the dummy variables, $\delta_{i k}$, will equal or be indistinguishable from zero. Thus, our first hypothesis is:

$$
\begin{aligned}
& \mathrm{H}_{0}: \delta_{\mathrm{ik}}=0 \\
& \mathrm{H}_{1}: \delta_{\mathrm{ik}} \neq 0
\end{aligned}
$$

Failure to reject the null asserts that market participants do not anticipate (1) changes in the firms' expected earnings; i.e., expected dividends, or (2) changes in the firms' risk-adjusted discount rates. Rejection of the null indicates investors are receiving returns in excess of (if positive) or less than (if negative) that which is predicted under the market model. 
Using the procedure of Mikkelson and Partch $(1985,1988)$ and MacKinley (1997), we calculate a zstatistic as the measure of significance to test the null hypothesis that the average abnormal daily returns for legislative events, across all financial institutions, is equal to zero. The dummy variable (legislative events) tstatistics obtained from the individual firm's market-model regressions are aggregated and divided by the square root of N; i.e., total observations that compose a particular sample. Under the null that the sum of the $\mathrm{t}$-statistics is equal to zero, the z-statistic, distributed asymptotically normal with mean zero and variance $\mathrm{N}$, is calculated as

$\mathrm{z}_{\mathrm{i}}=\frac{1}{\sqrt{\mathrm{N}}} \sum_{\mathrm{j}=1}^{\mathrm{n}}\left[\sum_{\mathrm{t}=\mathrm{t}_{1}}^{\mathrm{t}_{2}} \mathrm{PE}_{\mathrm{jt}} / \sqrt{\operatorname{Var} \sum_{\mathrm{t}=\mathrm{t}_{1}}^{\mathrm{t}_{2}} \mathrm{PE}_{\mathrm{jt}}}\right]$, or $\mathrm{z}_{\mathrm{i}}=\frac{\sum_{\mathrm{j}=1}^{\mathrm{n}} \mathrm{t}_{\mathrm{ij}}}{\sqrt{\mathrm{N}}}$ for $\mathrm{i}=1$ to 12

where,

$t_{1}$ and $t_{n}=$ the first and last days of the event interval, respectively

$\mathrm{PE}_{\mathrm{jt}}=$ the prediction error (abnormal return) of firm $\mathrm{j}$ for day $\mathrm{t}$

$\mathrm{t}_{\mathrm{ij}}=$ event $\mathrm{i}$-statistic for firm $\mathrm{j}$

$\mathrm{N}=$ the number of observations (i.e., the number of firms -t-statistics - in the sample)

H2: For each of the twelve major legislative events, the average abnormal returns will be equal for all banks, regardless of size.

A t-test is used to confirm the statistical significance of the difference in the parameter estimates (abnormal returns coefficients) for the dummy variables. Thus, our second hypothesis is

$$
\begin{aligned}
& \mathrm{H}_{0}: \mu_{\mathrm{H}}-\mu_{\mathrm{L}}=0 \\
& \mathrm{H}_{1}: \mu_{\mathrm{H}}-\mu_{\mathrm{L}} \neq 0
\end{aligned}
$$

where,

$\mu_{\mathrm{H}}=$ the mean return of event day stock returns for financial institutions with total assets greater than or equal to \$1 billion

$\mu_{\mathrm{L}}=$ the mean return of event day stock returns for financial institutions with total assets less than $\$ 1$ billion

This allows us to determine if large bank stockholders have a different market reaction than that of small bank stockholders. Given the nature of the key provisions of the DFA legislation and its seemingly disproportionate effect on larger institutions, it would not be surprising to see a rejection of hypothesis H2.

\section{RESULTS}

H1: For each of the twelve major legislative events, the average abnormal returns equal zero.

Average daily abnormal returns, the results of multivariate regression analyses used to measure investor response to the twelve major legislative events necessary to move the DFA through the law-making process, and their corresponding $\mathrm{z}$-statistics are reported in Table 4.

These test results of hypothesis H1 indicate a statistically significant market response in five of the twelve event announcement periods for the entire sample and an additional sixth significant response for the sub-sample of large banks. The six events triggering a significant market reaction include: 
- $\quad$ Financial regulatory reform proposal (D1)

- $\quad$ Announcement of the Volcker rule and resistance to the Senate version (D5)

- $\quad$ Revision of Senate version with compromises (D6)

- $\quad$ Passage of the Senate version (D9)

- $\quad$ Reconciliation in Conference Committee (D10)

- $\quad$ Final passage in the House (D11)

With a single exception, all statistically significant events yielded average abnormal return coefficients (absolute values) of less than one-quarter percent. The one exception was D5 in which the Volcker Rule was announced and resistance was noted to the Senate version; here a nearly two percent abnormal return coefficient was measured. The data also indicate that all six of the significant market reactions were positive; thus, we can conclude that the market was generally positive in seeing legislative progress being made to address the recent economic crisis. This positive response is greatest when the legislative response is comprehensive yet moderate.

Table 4: Summary of Abnormal Return Regression Results $f$

or All Banks, Large Banks over \$1 Billion in Assets, and Small Banks Less than \$1 Billion in Assets

\begin{tabular}{|c|c|c|c|}
\hline & $\begin{array}{c}\text { All } \\
(n=366)\end{array}$ & $\begin{array}{c}\text { Assets } \geq \$ 1 B \\
(n=222)\end{array}$ & $\begin{array}{c}\text { Assets }<\$ 1 B \\
(n=144)\end{array}$ \\
\hline Event & Coefficient & Coefficient & Coefficient \\
\hline \multirow[t]{2}{*}{ D1 } & 0.004231045 & 0.003723681 & 0.005013231 \\
\hline & $(3.1486907)^{*}$ & $(2.887246234) *$ & $(1.434916667)$ \\
\hline \multirow[t]{2}{*}{ D2 } & 0.000451751 & -0.001978522 & 0.004198423 \\
\hline & $(0.013538147)$ & $(-0.709143488)$ & $(0.902083333)$ \\
\hline \multirow[t]{2}{*}{ D3 } & -0.00020617 & -0.001290945 & 0.001466193 \\
\hline & $(-0.635299757)$ & $(-1.184791784)$ & $(0.45825)$ \\
\hline \multirow[t]{2}{*}{ D4 } & -0.001459181 & -0.002404742 & -.0000014409 \\
\hline & $(-0.189690869)$ & $(-0.445983199)$ & $(0.251333333)$ \\
\hline \multirow[t]{2}{*}{ D5 } & 0.019878057 & 0.029625586 & 0.004850616 \\
\hline & $(12.23362359) *$ & $(15.18282517) *$ & $(0.652)$ \\
\hline \multirow[t]{2}{*}{ D6 } & 0.002594077 & 0.003514251 & 0.001175476 \\
\hline & $(2.006729717) * *$ & $(2.201794555) * *$ & $(0.465416667)$ \\
\hline \multirow[t]{2}{*}{ D7 } & -.0000024003 & -0.001120268 & 0.001720979 \\
\hline & $(-0.971610325)$ & $(-1.482181032)$ & $(0.291333333)$ \\
\hline \multirow[t]{2}{*}{ D8 } & 0.001845463 & 0.00240681 & 0.000980053 \\
\hline & $(1.224496636)$ & $(1.400367109)$ & $(0.213416667)$ \\
\hline \multirow[t]{2}{*}{ D9 } & 0.002300452 & 0.006492803 & -0.004162755 \\
\hline & $(1.918705627)$ & $(3.844180537) *$ & $(-1.714166667)$ \\
\hline \multirow[t]{2}{*}{ D10 } & 0.003565959 & 0.005627032 & 0.000388471 \\
\hline & $(4.600251853)^{*}$ & $(5.317166732) *$ & $(0.732)$ \\
\hline \multirow[t]{2}{*}{ D11 } & 0.002401365 & 0.00497669 & -0.001568929 \\
\hline & $(3.923762676) *$ & $(5.292937998) *$ & $(-0.316416667)$ \\
\hline \multirow[t]{2}{*}{ D12 } & 0.000460661 & -0.000869568 & 0.002511431 \\
\hline & $(-0.316604462)$ & $(-1.190161033)$ & $(0.973)$ \\
\hline
\end{tabular}

$*, * *, * * *$ Indicates significant at the $1 \%, 5 \%$, and $10 \%$ level.

H2: For each of the twelve major legislative events, the average abnormal returns will be equal for all banks, regardless of size.

The next question addressed is, "Which banks have the most at stake in the legislative outcome?" We see from the results in Table 5 that large banks generated a significantly larger market reaction to DFA than did the smaller banks. In fact, banks with less than $\$ 1 \mathrm{~B}$ in assets showed no significant abnormal returns at all to any of the event dates. Five of the event dates corresponded to significant differences in mean reactions:

- $\quad$ Bill introduced in the Senate (D2)

- $\quad$ Announcement of the Volcker rule and resistance to the Senate version (D5)

(C) 2012 The Clute Institute http://www.cluteinstitute.com/ 
- $\quad$ Passage of the Senate version (D9)

- $\quad$ Reconciliation in Conference Committee (D10)

- $\quad$ Final passage in the House (D11)

Four of the five dates with differences in reaction also correspond to key dates highlighted in the results of Table 4. Only D2 was unique, though it was the weakest of the five statistically significant difference of means $(\mathrm{t}=$ 1.693).

Table 5: Difference of Means Test between Small Banks of Less than \$1 Billion in Assets and Large Banks of Greater than \$1 Billion in Assets

\begin{tabular}{|c|c|c|c|}
\hline & $\begin{array}{c}\text { Assets }<\$ 1 B \\
(n=144)\end{array}$ & $\begin{array}{c}\text { Assets } \geq \$ 1 B \\
(n=222)\end{array}$ & \\
\hline Event & Coefficient & Coefficient & Difference t-stat \\
\hline D1 & 0.005013231 & 0.003723681 & $(0.42541897)$ \\
\hline D2 & 0.004198423 & -0.001978522 & $(1.693626294) * * *$ \\
\hline D3 & 0.001466193 & -0.001290945 & $(0.883072737)$ \\
\hline D4 & -.0000014409 & -0.002404742 & $(0.919427566)$ \\
\hline D5 & 0.004850616 & 0.029625586 & $(-3.87082656) *$ \\
\hline D6 & 0.001175476 & 0.003514251 & $(-0.909928049)$ \\
\hline D7 & 0.001720979 & -0.001120268 & $(0.885705466)$ \\
\hline D8 & 0.000980053 & 0.00240681 & $(-0.633357499)$ \\
\hline D9 & -0.004162755 & 0.006492803 & $(-4.360959819) *$ \\
\hline D10 & 0.000388471 & 0.005627032 & $(-1.771070244) * * *$ \\
\hline D11 & -0.001568929 & 0.00497669 & $(-2.87203753)^{*}$ \\
\hline D12 & 0.002511431 & -0.000869568 & $(1.145394188)$ \\
\hline
\end{tabular}

\section{CONCLUSION}

The Dodd-Frank Wall Street Reform and Consumer Protection Act is one of the most sweeping pieces of legislation to affect financial institutions in recent history. Though certain of its provisions have been considered and debated for years, it took the global financial crisis of 2008 to provide enough impetus to drive this massive 2000-pages piece of legislation to fruition. Within the context of financial crisis, the markets seemed to want some degree of enhanced stability through oversight, yet simultaneously feared overreaction by legislators. In this paper we empirically measure the market's reaction to the emergence of the Dodd-Frank Act. In five of the twelve related key legislation dates, markets showed a significant positive reaction. We also find evidence that only large banks reacted to the passage of the Dodd-Frank Act since they have the most at stake.

The passage of Dodd-Frank legislation is only part of the story, however. Under the guidelines of the bill, most of the details of implementation are yet to be specified by the banking regulatory agencies. Meanwhile, this process is being influenced by the public hearings and lobbying process. How the markets respond to this subsequent phase of the implementation of DFA merits further research.

\section{ACKNOWLEDGMENT}

The authors would like to thank William Christiansen of Florida State University for generous data support.

\section{AUTHOR INFORMATION}

George Turk holds a Ph.D. in finance from Florida State University and an MBA from Auburn University. His research interests include corporate finance and investments. He has prior managerial experience in the retail sector.

Philip Swicegood is the R. Michael James Professor of Finance at Wofford College. He holds a Ph.D. in finance from Florida State University and an MBA from the University of Texas at Austin. He has worked in the banking industry as a banking regulator for the Office of the Comptroller of the Currency. E-mail: swicegoodpg@wofford.edu (Corresponding author) 


\section{REFERENCES}

1. Aharony, J., Saunders, A., and Swary, I. (1988). The effects of DIDMCA on bank stockholders' returns and risk. Journal of Banking \& Finance, 12(3), 317-331.

2. Akhigbe, A. and Whyte, A. M. (2004). The Gramm-Leach-Bliley Act of 1999: Risk Implications for The Financial Services Industry. Journal of Financial Research, 27(3), 435-446.

3. Allen, P.R., and Wilhelm, W. J. (1988). The Impact of the 1980 Depository Institutions Deregulation and Monetary Control Act on Market Value and Risk: Evidence from the Capital Markets. Journal of Money, Credit and Banking, 20(3), 364-380.

4. Ball, R., and Brown, P. (1968). An Empirical Evaluation of Accounting Income Numbers. Journal of Accounting Research, 6(1), 159-78.

5. Barth, J., and Jahera, J. (2010). U.S. Enacts Sweeping Financial Reform Legislation. Journal of Financial Economic Policy, 2(3), 192-195.

6. Binder, J.J. (1985). On the Use of the Multivariate Regression Model in Event Studies. Journal of Accounting Research, 23(1), 370-383.

7. Binder, J.J. (1985). Measuring the Effects of Regulation with Stock Price Data. The RAND Journal of Economics, 16(2), 167-183.

8. $\quad$ Brown, S.J., and Warner, J.B. (1985). Using Daily Stock Returns: The Case of Event Studies. Journal of Financial Economics, 14(1), 3-31.

9. Bryant, S. K., and Martzoukos, S. H. (1998). The Impact of the Financial Institutions Reform, Recovery, and Enforcement Act (FIRREA) on the Value of S\&L Stocks. Journal of Economics and Finance, 22(2), 67-76.

10. Cornett, M., and Tehranian, H. (1989). Stock Market Reactions to the Depository Institutions Deregulation and Monetary Control Act of 1980. Journal of Banking \& Finance, 13(1), 81-100.

11. Cornett, M., and Tehranian, H. (1990). An Examination of the Impact of the Garn-St. Germain Depository Act of 1982 on Commercial Banks and Savings and Loans. The Journal of Finance, 45(1), 95-111.

12. Fama, E. F., Fisher, L., Jensen, M., and Roll, R. (1969). The Adjustment of Stock Prices to New Information. International Review, 10(1), 1-21.

13. Goa, Y., Liao, S., and Wang, X. (2011). The Economic Impact of the Dodd Frank Act of 2010: Evidence from Market Reactions to Events Surrounding the Passage of the Act. Working Paper.

14. Liang, Y., Mohanty, S., Song, F. (1996). The Effect of the Federal Deposit Insurance Corporation Improvement Act (FDICIA) of 1991 on Bank Stocks. Journal of Financial Research, 19(1), 229-242.

15. MacKinlay, A. C. (1997). Event Studies in Economics and Finance. Journal of Economic Literature, 35(1), 13-39.

16. Malatesta, P. (1986). Measuring Abnormal Performance: The Event Parameter Approach Using Joint Generalized Least Squares. Journal of Financial and Quantitative Analysis, 21(1), 27-38.

17. Mikkelson, W., and Partch, M. (1985). Stock Price Effects and Costs of Secondary Distributions. Journal of Financial Economics, 14(1), 165-194.

18. Mikkelson, W., and Partch, M. (1988). Withdrawn Security Offerings. The Journal of Financial and Quantitative Analysis, 23(2), 119-133.

19. Sundaram, S., and Rangan, N., and Davidson W. (1992). The Market Valuation Effects of the Financial Institutions Reform, Recovery and Enforcement Act of 1989. Journal of Banking \& Finance, 16(6), 1097 1122.

20. Swicegood, P. (1997). The Market's Evaluation of FDICIA: An Examination Of The Empirical Evidence. The Southern Business \& Economic Journal, 20(4), 245-262.

21. Thompson, R. (1985). Conditioning the Return-Generating Process on Firm Specific Events: A Discussion of Event Study Methods. Journal of Financial and Quantitative Analysis, 20(1), 151-168.

22. Zellner, A. (1962).An Efficient Method of Estimating Seemingly Unrelated Regressions and Tests for Aggregation Bias. Journal of the American Statistical Association, 57(2), 348-368. 


\section{NOTES}

